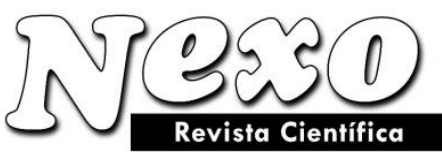

Vol. 34, No. 01, pp. 363-369/Marzo 2021

\title{
The complexities of statistical measurements of new social processes: a system of Downshifting indicators
}

\section{Las complejidades de las medidas estadísticas de nuevos procesos sociales: un sistema de indicadores Downshifting}

\author{
Mikhail Vladimirovich Karmanov ${ }^{1, *}$, Irina Petrovna Gladilina ${ }^{2}$, Anatoly Vladimirovich \\ Zavrazhin $^{3}$, Irina Vladimirovna Shubina ${ }^{4}$, Svetlana Aleksandrovna Sergeeva ${ }^{2}$ \\ ${ }^{1}$ Plekhanov Russian University of Economics, Moscow, Russia. \\ ${ }^{2}$ Moscow City University of Management of the Government of Moscow named after Yu.M. Luzhkov, \\ Moscow, Russia. \\ ${ }^{3}$ Gubkin Russian State University of Oil and Gas, Moscow, Russia. \\ ${ }^{4}$ Moscow Social and Pedagogical Institute, Moscow, Russia. \\ *karmanov.m.v@mail.ru
}

(recibido/received: 15-October-2020; aceptado/accepted: 11-January-2021)

\begin{abstract}
In the 21st century, new social processes that used to be considered illogical, unusual, and even impossible in the recent past are becoming increasingly widespread. Downshifting implying deliberate rejection of the benefits of modern civilization should undoubtedly be viewed as one of such processes. In various countries and corners of the planet, the scale of the development of downshifting has now acquired such a great magnitude that acting like nothing is happening would be both impossible and wrong. Meanwhile, an unequivocal perception of downshifting as an exclusively favorable or unfavorable process has not yet formed in society. In this context, attempts at measuring and statistically evaluating the various parameters of downshifting draw great interest from the point of science and practice. However, it has to be admitted that statistical science somewhat lags behind the present demands and needs of society since the system of downshifting indicators providing its comprehensive characteristic and allowing for a relatively clear answer to the question of the actual role of such an unusual social process has not yet been developed. In this context, the present article examines the specific characteristics of the quantitative analysis of downshifting, analyses various approaches to creating a downshifting statistics indicator system, and presents the authors' propositions considering the structure and components of the system of downshifting indicators allowing not only comprehensively demonstrating the scale, structure, distribution, and intensity of this process, but also addressing its socio-economic results and consequences.
\end{abstract}

Keywords: downshifting; downshifting measurement; downshifting indicators; downshifting indicator system.

\section{RESUMEN}

En el siglo XXI, se están generalizando cada vez más los nuevos procesos sociales que solían considerarse ilógicos, inusuales e incluso imposibles en el pasado reciente. Indudablemente, el cambio descendente que 
implica el rechazo deliberado de los beneficios de la civilización moderna debe considerarse como uno de esos procesos. En varios países y rincones del planeta, la escala del desarrollo del cambio descendente ha adquirido ahora una magnitud tan grande que actuar como si nada estuviera sucediendo sería imposible e incorrecto. Mientras tanto, todavía no se ha formado en la sociedad una percepción inequívoca de la reducción de marcha como un proceso exclusivamente favorable o desfavorable. En este contexto, los intentos de medir y evaluar estadísticamente los diversos parámetros del cambio descendente despiertan un gran interés desde el punto de vista científico y práctico. Sin embargo, hay que admitir que la ciencia estadística va un poco por detrás de las demandas y necesidades actuales de la sociedad, ya que el sistema de indicadores descendentes proporciona su característica integral y permite una respuesta relativamente clara a la pregunta sobre el papel real de un proceso social tan inusual. aún no se ha desarrollado. En este contexto, el presente artículo examina las características específicas del análisis cuantitativo del downshifting, analiza varios enfoques para la creación de un sistema de indicadores estadísticos de downshifting, y presenta las propuestas de los autores considerando la estructura y componentes del sistema de indicadores de downshifting que permiten no solo de manera integral demostrando la escala, estructura, distribución e intensidad de este proceso, pero también abordando sus resultados y consecuencias socioeconómicas.

Keywords: cambio descendente; medición de cambio descendente; indicadores de cambio descendente; sistema indicador de cambio descendente.

\section{INTRODUCTION}

Along with other countries, Russia has recently come into close contact with the social process of downshifting which has been growing increasingly widespread.

According to official data, downshifting is currently the most developed in Australia and the USA (Hamilton, Mail, 2003). Public opinion polls indicate that from a quarter to a third of the population of these countries have already been actively involved in this process. In European countries, the proportion of residents affected by downshifting is about half as much as in Australia, and in Russia, it is half as much as in Europe (Khrystenko, 2010).

At the same time, the ambiguous nature of theoretical and practical assessments of downshifting draws special attention to itself as it can be reduced to diametrically opposite viewpoints:

- downshifting is a positive social process reflecting the return of humanity to its origins and traditional values (Merzliakova, 2008);

- downshifting is a negative social process associated with a psychological breakdown, career degradation, and inability to keep up with the high paced pace of modern life (Gladkov, 2012).

Historically speaking, downshifting has emerged such a long time ago that it is highly probable that accurately and unambiguously establishing its origin is impossible. The divine Buddha himself purposefully devoted himself to comprehending the eternal questions of existence leaving all the riches and pleasures of this world behind. In modern times, downshifting is often interpreted as a deliberate shift to a slower pace of life, from high income and the stress accompanying it to mental comfort with a much lesser reward (Moroz, 2009).

In our opinion, to avoid hasty conclusions and comprehensively understand the place, role, and social significance of downshifting, a comprehensive and detailed understanding of the parameters of such a contradictory and rather peculiar process is needed. Understanding said parameters is hardly possible 
without the involvement of the science of statistics tasked with collecting, processing, systematizing, and analyzing quantitative information.

It seems that downshifting statistics present the tool that can help to understand both the content and the nature of this process focused on a qualitative change in a person's position in the existing system of social coordinates.

\section{METHODS}

From a methodological standpoint, a variety of quantitative indicators can be used to characterize the most diverse aspects of downshifting. Meanwhile, the issues accompanying attempts at measuring the scale, prevalence, and consequences of the aforementioned social changes are highly important to address. From our standpoint, they can be reduced to the following key aspects:

1) the existence of a certain vacuum, a lack of applied research aimed at assessing the most vital parameters of downshifting;

2) a certain reluctance of society to move towards the formation of an information base making it easier to identify the main quantitative characteristics of downshifting;

3) the lack of a proper understanding of the importance of developing and justifying the downshifting indicator system, especially in terms of its superiority individual indicator, even highly illustrative.

A theoretical analysis of scientific publications suggests that downshifting is often considered by specialists as an object of psychology (Prikhidko, 2008), sociology (Kozyreva, Ovechkina, 2012), management (Kesheva, 2016), and several other sciences but is extremely rarely viewed as an object of statistics (Makhova, Karmanov, 2017). This finding can indicate two things: either that the scientific community is failing to understand the importance and relevance of downshifting as a phenomenon of modern life, or that statistical science is somewhat lagging behind the urgent and constantly changing practical needs. After all, the above-mentioned quantitative scale of the prevalence of downshifting in individual countries does not in any way reflect the significance of individuals' social shift associated with their conscious transition to a slower pace of life. Therefore, regular registration of downshifting parameters not only can but has to draw increased attention, especially in the context of an adequate understanding of its place and role in society.

Unfortunately, we have to admit that many downshifting parameters cannot be assessed objectively due to the lack of an adequate information base. The absence of well-organized statistical accounting leads to the fact that for the most part, various social movements associated with consciously moving down the career ladder or away from many so-called popular trends in modern consumer society overshadow downshifting or leave it out of the scope of attention of not only science but also practice focused on optimizing and increasing the efficiency of social processes. To a certain extent, it can be concluded that the state deliberately avoids spending time and money on tracking the process mostly affecting individual citizens forgetting the fact that its scale has already transcended the scope of a private or insignificant impulse that can be safely ignored.

\section{RESULTS}

Various indicators can be used to quantify certain aspects of downshifting. From a theoretical point of view, they can be focused on the following interrelated but independent aspects:

a) on downshifters as first-hand participants in the considered social process; 
b) on the features of downshifting itself as a specific social movement falling outside of the generally accepted concept of traditional upward career growth;

c) on the consequences of downshifting at the personal, family, collective, and state levels.

The synthesis of these aspects provides a solid foundation for understanding the fact that a comprehensive applied study of downshifting as a multifaceted social process can only be conducted using a system of indicators since in this case, individual indicators or indicator groups will most definitely fail to reflect the whole spectrum of the content of a social movement focused on consciously slowing down the pace of life (Zavrazhin, Karmanov, 2017).

Moreover, focusing on a system of indicators considering downshifting can be justified by the ambiguous nature of the object which, according to many specialists, has both positive and negative aspects. The positive direction of reasoning typically emphasizes that the decrease in workload helps to eliminate stress and improve health and opens up previously blocked opportunities for creativity and rethinking one's life. The negative direction of reasoning indicates the loss of a significant part of the previously available income leading to a decrease in the level of comfort, as well as to an increased likelihood of family and labor conflicts arising from downshifting itself.

Logical structurization and substantiation of the sequence of indicators selected for the quantitative characterization of the object of research has great theoretical significance in solving the problem of creating a system of downshifting indicators. In this context, it is crucial to answer the following questions.

1) How many and which sections (or constituent blocks) should be included in the downshifting indicator system?

2) How should these sections be placed to organically complement one other and comprehensively characterize downshifting?

3) What indicators should be included in the dedicated sections of the downshifting indicator system?

In our opinion, the posed questions are by no means rhetorical since the logical scheme of applied research of downshifting as a process of transformation of the life position of the members of modern society depends on resolving them.

Structurization of the downshifting statistics indicator system presents an important scientific objective since its completion predetermines the key aspects to focus on. It should be noted that certain traditions, rules, and even stereotypes of depicting reality have formed in the practice of statistics. Among them, it is most often customary to identify the following parameters of socio-economic phenomena and processes:

- absolute size (scale);

- relative size (scale);

- structure (essential compound elements);

- prevalence;

- development intensity; 
- development effectiveness;

- consequences of development, etc.

Regarding downshifting, in our opinion, these parameters can be accumulated into the following sequence of enlarged sections (Figure 1).

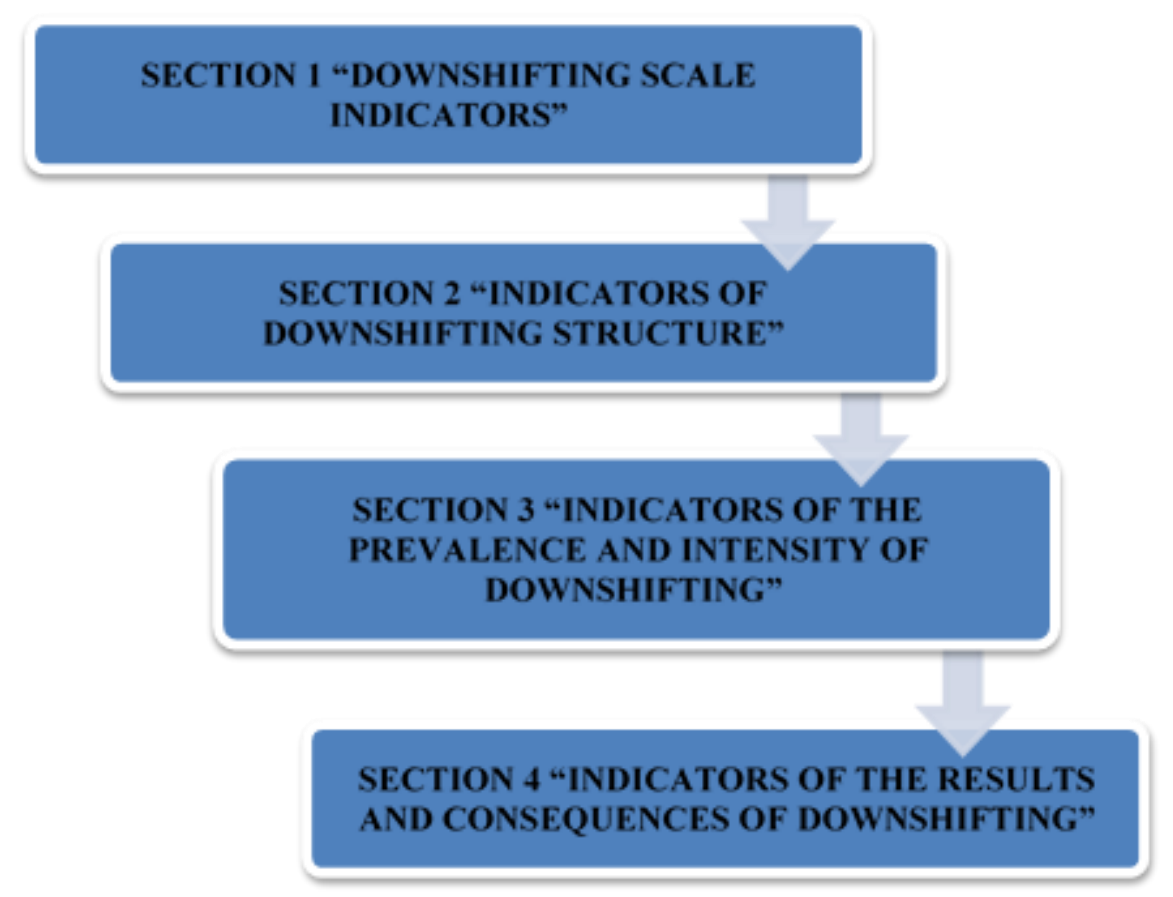

Figure 1. Downshifting indicator system

\section{DISCUSSION}

The proposed structure is centered around the fact that the characteristic of any social process including downshifting typically starts with reflecting its absolute and relative size which essentially answers the question of the scale of the object under study. Absolute size refers to the number of downshifting cases that can be examined regarding both separate individuals and whole families (group downshifting). The relative size differs from that in that they are associated with the share or proportion of people involved in the social transition to a slower pace of life. Moreover, combining the absolute and relative parameters allows reflecting the scale of the examined process more comprehensively.

The need to supplement the first section with the block of downshifting structure indicators is objectively determined by the fact that the examined social process affects various social strata. Thus, the community of downshifters may include both men and women, urban and rural residents, youth, pensioners, managers, workers, etc. In this regard, it is necessary to pay attention to the structural features of the downshifter contingent in demographic and socio-economic aspects. Accordingly, the solution to this problem is impossible without structural indicators that ground the assessment of the process under study.

The role of the third section of indicators presented in Figure 1 boils down to the fact that indicators of the size and structure of downshifting do not provide information about the prevalence of this social process and the intensity of its development. The prevalence of downshifting can be considered concerning both the population and the territory. In other words, comparisons can be made based on the demographic and 
territorial components answering the question of how often downshifters are found among all residents of the country (region, etc.), as well as in a particular territory. Assessment of the downshifting development intensity implies measuring the rate of change in the number of downshifters over time. Taken together, the prevalence and intensity of development not only consistently complement the size and structure of the considered social process but also reveal its role and place in society.

Finally, the indicators of the results and consequences of downshifting development logically complete the structure as a whole as they focus on the fact that the size, structural features, prevalence, and intensity of changes in social processes ultimately determine the parameters of the socio-economic situation. In other words, these parameters characterize what the pursuit of a slower pace of life in the most diverse aspects of human activity leads to. Without them, the downshifting indicator system is incomplete and does not allow obtaining a comprehensive assessment of the research object.

Considering the specific content of each of the four sections of the downshifting indicator system, we can focus on the following indicators:

O downshifting scale indicators: the number of downshifters; the number of downshifter families; the share of downshifters in the total population; the proportion of downshifters among men and women, urban and rural residents, and other socio-demographic groups of the population; the share of downshifters among workers, managers, persons with higher education, and other socio-economic groups of the population, etc.;

O downshifting structure indicators: distribution of downshifters by sex, age, nationality, place of residence, territory, education, professions, income, and other demographic and socio-economic groups of the population, etc.;

O downshifting prevalence and intensity indicators: the number of downshifters per 1,000 people of working age in general, as well as by gender, place of residence, territory, and other demographic and socio-economic characteristics; the rate of growth of the number of downshifters in general, as well as by gender, age, nationality, place of residence, territory, education, professions, income, and other demographic and socio-economic characteristics, etc.;

0 indicators of downshifting results and consequences: birth rate in downshifter families; downshifter mortality, marriage, and divorce rates; coefficients of downshifters' migration arrival, departure, and growth; the coefficient of downshifters' migration settledness; downshifters' employment and unemployment rates; involvement of downshifters in social and political activities, etc.

\section{CONCLUSION}

In conclusion, it is necessary to emphasize that the relevance of resolving the theoretical and practical issues of creating a downshifting indicator system examined in the present article is predetermined by the place this process is starting to occupy in modern society. Moreover, its development and prevalence demonstrate the need to improve the comprehensive assessment of people's transition to a slower pace of life which significantly transforms many social values and leads to results that are not yet completely comprehended by modern society.

\section{REFERENCES}

Gladkov, P.A. (2012). Daunshifting i anomiia: klassicheskaia teoriia R.K. Mertona i ee sovremennoe prilozhenie [Downshifting and anomie: the classical theory of R.K. Merton and its modern implementation]. Retrieved from: http://human.snauka.ru/2012/03/1868 
Hamilton, C., Mail, E. (2003). Downshifting in Australia: A Sea change in a Pursuit of Happiness. The Australia Institute, Discussion Paper, 50.

Kesheva, R.T. (2016). Instrumenty upravleniia daunshiftingom [Downshifting management instruments]. In collection: Sovremennyi stil upravleniia sbornik nauchnykh statei.

Khrystenko, A. (2010). Daunshifting - novyi sotsialnyi trend. [Downshifting - a new social trend]. Retrieved from: http://delovoymir.biz/ru/articles/view/?did=8745

Kozyreva, L.D., Ovechkina, Ya.V. (2012). Daunshifting kak obyekt sotsiologicheskogo analiza [Downshifting as an object of sociological analysis]. Vestnik Orlovskogo gosudarstvennogo universiteta. Series: Novye gumanitarnye issledovaniia., 8, 68-70.

Makhova, O.A., Karmanov, M.V. (2017). Daunshifting kak obekt statisticheskogo issledovaniia [Downshifting as an object of statistical study]. In collection: Statisticheskie metody issledovaniia sotsialno-ekonomicheskikh i ekologicheskikh sistem regiona. Materialy Mezhdunarodnoi nauchnoprakticheskoi konferentsii.

Merzliakova, V. (2008). Alternativnye modeli uspeshnosti v sovremennoi kulture: daunshifting [Alternative models of success in the modern culture: downshifting]. The Russian Public Opinion Herald, $4,33-42$.

Moroz, M. (2009). Daunshifting - begstvo "ot" ili "k"? [Downshifting - running "from" or "towards"?]. Electronic resource: http://www.psychology.su/2009/04/30/daunshifting-begstvo-ot-ili-k/

Prikhidko, A.I. (2008). Daunshifting kak sotsialno-psikhologicheskii fenomen [Downshifting as a social and psychological phenomenon]. Psikhologicheskie issledovaniia: elektronnyi nauchnyi zhurnal, 1, 8 .

Zavrazhin, A.V., Karmanov, M.V. (2017). Aktualnye voprosy issledovaniia daunshiftinga [Relevant issues of downshifting research]. Pravo i obrazovaniie, 11, 94-101. 